\title{
Chloride-liberal fluids are associated with acute kidney injury after liver transplantation
}

\author{
Ashraf Nadeem ${ }^{1}$, Nawal Salahuddin ${ }^{1 *}$, Alyaa El Hazmi ${ }^{2}$, Mini Joseph ${ }^{1}$, Balsam Bohlega ${ }^{1}$, Hend Sallam³, \\ Yasser Sheikh ${ }^{3}$ and Dieter Broering ${ }^{3}$
}

\begin{abstract}
Introduction: Acute kidney injury (AKI) occurs frequently after liver transplantation and is associated with significant morbidity and mortality. Recent evidence has linked the predominant usage of 'chloride-liberal' intravenous fluids, such as $0.9 \%$ saline to the development of renal dysfunction in general critically ill patients. We compared the effects of perioperative fluid types on AKI in liver transplant recipients.

Methods: An observational analysis of liver transplant recipients over a 33-month period, between January 2010 and September 2013, was performed. Intensive care unit database and patient records were analyzed for determinants of early postoperative AKI. Univariate and multivariate regression analysis was carried out using a two-tailed $P$ value less than 0.05 to establish significance. The institutional Research Ethics Committee approved the study methodology (RAC no. 2131 073).
\end{abstract}

Results: One hundred and fifty-eight liver transplants were performed, AKI developed in 57 (36.1\%) patients: 39 (68.4\%) fully recovered, 13 (22.8\%) developed chronic renal failure and 10 (17.5\%) required long-term hemodialysis. On univariate regression analysis, AKI was significantly associated with greater than 3,200 $\mathrm{ml}$ of chloride-liberal fluids infused within the first postoperative day ( $\mathrm{HR} 5.9,95 \% \mathrm{Cl} 2.64,13.2, P<0.001)$, greater than $1,500 \mathrm{ml}$ colloids received in the operating room (hazard ratio $(\mathrm{HR}) 1.97,95 \% \mathrm{Cl} 1.01,3.8, P=0.046$ ), vasopressor requirement for 48 hours posttransplant ( $\mathrm{HR} 3.34,95 \% \mathrm{Cl} 1.55,7.21, P=0.002)$, hyperchloremia at day 2 ( $\mathrm{HR} 1.09,95 \% \mathrm{Cl} 1.01,1.18$, $P=0.015)$ and preoperative model for end-stage liver disease (MELD) score (HR 1.08,95\% Cl 1.03, 1.13, $P<0.001$ ). After stepwise multivariate regression, infusion of greater than 3,200 $\mathrm{ml}$ of chloride-liberal fluids (HR 6.25, 95\% $\mathrm{Cl} 2.69,14.5, P<0.000)$ and preoperative MELD score (HR 1.08,95\% Cl 1.02, 1.15, $P=0.004)$ remained significant predictors for AKI.

Conclusions: In a sample of liver transplant recipients, infusion of higher volumes of chloride-liberal fluids and preoperative status was associated with an increased risk for postoperative AKI.

\section{Introduction}

Acute kidney injury (AKI) occurs both frequently after liver transplantation, reportedly in 29 to $60 \%$ recipients [1-3] and, irrespective of severity, confers an increased risk of death [4]. This increase in risk of mortality extends from the early postoperative period ( 28 days) and up to one year after transplantation [1]. The National Institute of Diabetes and Digestive and Kidney Disease (NIDDK) long-term follow-up study ascribed a 2.66 hazard

\footnotetext{
* Correspondence: salahuddin.nawal@gmail.com

'Department of Adult Critical Care Medicine, King Faisal Specialist Hospital and Research Centre, At Takhassusi, Al Madhar Ash Shamali, Riyadh 12713, Saudi Arabia

Full list of author information is available at the end of the article
}

ratio (HR) directly attributable to renal dysfunction developing after liver transplantation [5].

Previously described risk factors for AKI in liver recipients are greater severity of illness pretransplant (higher model for end-stage liver disease (MELD) scores, intensive care unit (ICU) admission, and coagulopathy), vasopressors, and greater transfusions in the immediate perioperative period [5-13]. However, very little is known about the effects of intravenous fluid selection (chloride-liberal versus chloride-restrictive) or the effects of fluid balance on the risk of renal injury. An overall fluid overload state leads to renal congestion, compromised renal blood flow and reductions in glomerular filtration rate (GFR) [14]. In critically ill patients, a positive fluid balance has been 
associated with increased mortality $[15,16]$ and poorer outcomes once AKI develops [17-19]. Recent evidence has highlighted the possible nephrotoxic effects of 'chloride-liberal' fluids ( $0.9 \%$ saline). Animal and human controlled studies have shown that infusions of chlorideliberal or solutions with supraphysiological chloride concentrations cause vasoconstriction of renal afferent arterioles, cortical hypoperfusion and decreased GFR [20-22]. In a recent pre- and postintervention study, restriction to chloride-restrictive fluids was associated with lower AKI and need for renal replacement therapy (RRT) as compared to chloride-liberal fluids [23]. Therefore, perioperative intravenous fluid selection and volume may prove to be a modifiable risk factor for the prevention of AKI. No similar data exists for liver transplant recipients. These patients clearly are at an increased risk of renal injury with mortal consequences. We hypothesized that AKI occurring in the early postoperative period after liver transplant may be associated with the use of chloride-liberal fluids and overall fluid overload causing renal congestion.

\section{Material and methods}

This study is reported following the STROBE statement checklist for observational studies [24]. All studies at our institution require ethical approval; the Office of Research Affairs (ORA) and ORA Research Ethics Committee approved the study (RAC no. 2131 073). Patient consent was waived by the Research Ethics Committee.

\section{Study design and setting}

This was an observational study of liver transplant recipients carried out at a tertiary care, university hospital over a 33-month period between January 2010 and September 2013.

\section{Operational definitions}

AKI was defined according to the risk, injury, failure, loss, end-stage renal failure (RIFLE) classification [25] of renal dysfunction, that is using both increases in creatinine from preoperative values and urine output measured as urine volume in milliliters/patient's baseline weight in kilograms/hour. Serum creatinine values were measured preoperatively and daily for up to the third postoperative day. Serum creatinine was measured using the COBAS Integra Creatinine plus ver. 2 assay (Roche Diagnostics Corp, Basel, Switzerland). This is an enzymatic method based on the determination of hydrogen peroxide after conversion of creatinine with the aid of creatininase, creatinase, and sarcosine oxidase. Patients were screened for the development of postoperative AKI on a daily basis until the third day.

Prolonged ICU stay was defined a priori as a cutoff value of the mean (or median for skewed data) ICU days after transplantation. Delayed weaning from mechanical ventilation was defined as $<3>$ days of invasive ventilation.

Chloride-liberal fluids were fluids containing supraphysiological concentrations of chloride $(0.9 \%$ saline, $20 \%$ and $5 \%$ albumin); chloride-restrictive fluids were fluids with chloride concentrations closer to plasma $(0.45 \%$ saline, Ringer's lactate).

\section{Participants}

Consecutive adult liver transplant recipients within the specified study period were included. Patients undergoing multiorgan transplantation were excluded.

Crystalloids used in the study patients were: lactated Ringer's (sodium chloride, potassium chloride, sodium lactate and calcium chloride) injection, $0.9 \%$ sodium chloride injection, USP, $0.45 \%$ sodium chloride injection, USP, manufactured by Baxter Healthcare Corp, Deerfield IL, USA. Colloids used were: human albumin $5 \%$ and 20\% manufactured by Biotest Pharma GmbH, Dreieich, Germany.

\section{Variables}

The primary outcome variable was the development of postoperative AKI. Other outcome variables studied were delayed weaning from mechanical ventilation, prolonged ICU stay (as defined above), ICU mortality, and 28-day mortality. Other variables collected were recipient demographic data, etiology of cirrhosis, comorbidities, posttransplant acute physiologic and chronic health evaluation II (APACHE II) scores, routine hematological, biochemical and organ dysfunction/physiological (AKI, vasopressors, RRT, mechanical ventilation) data, fluid balance, fluids and blood products received at admission to ICU and daily up to day 3 posttransplantation.

\section{Data sources/measurement}

In our ICU, patient data is routinely entered into an ICU database. Data entry is by a critical care nurse dedicated to the database. Patient data required for the study and missing from the database was extracted by the research team (AH, HS, BB, AN) from the patient's electronic medical records and laboratory computerized results.

\section{Statistical analysis}

Continuous data was tested for normality: measures of central tendency were compared as means \pm standard deviations (SD) using the Student's $t$ test for normally distributed variables and as medians (interquartile range, IQR) using the Mann-Whitney $U$ test for skewed data. Categorical variables were compared using the chi-square test or the Fisher exact test for $\mathrm{n}<5$. Fluid volumes were dealt with as continuous variables while fluid types were classified into either 'chloride-liberal' or 'chloride-restrictive' and correspondingly dealt with as continuous variables. 
Logistic regression analysis was performed to determine the predictive ability of variables for AKI, prolonged ICU stay and prolonged mechanical ventilation. Univariate and multivariate techniques were used, and for multivariate regression, a backward mode with a threshold 0.15 was used for elimination. Multivariate associations were reported as odds ratios (OR) with 95\% confidence intervals (CIs). A two-sided $P$ value of $<0.05$ was considered as statistically significant. All analyses were carried out using IBM SPSS version 22.0 (IBM Corp, Armonk, NY, USA).

\section{Results}

\section{Participants and descriptive data}

One hundred and fifty-eight liver transplants were performed during the study period. Of these, 104 (65.8\%) were living donor-related transplants, 53 (33.5\%) cadaveric and 1 $(0.6 \%)$ was a retransplant. Mean age of transplant recipients was $52.3 \pm 13.3$ years and 66 (42\%) were female, mean body mass index (BMI) was $26.8 \pm 6$ (range 14, 49). Mean MELD score at time of transplantation was 19.4 \pm 7.7 (range 6, 45), with mean baseline creatinine $88.7 \mathrm{micromol} / \mathrm{L} \pm 56$ (range 27, 350). Transplant recipients had end-stage liver disease caused by: hepatitis $\mathrm{C}$ in 60 (38\%) patients, hepatitis B in 34 (21.5\%), cryptogenic liver disease in 41 (25.9\%), autoimmune disease in 9 (5.7\%) and others (bilharziasis, congenital hepatic cirrhosis, Budd-Chiari, Wilson's disease) in $14(9 \%)$ recipients. Fifty-two (32.9\%) patients had hepatocellular carcinomas.

All patients were transferred to the ICU posttransplant. On arrival, transplant recipients were in a positive fluid balance of $8.48 \pm 2.3$ liters fluid, having received $1.7 \pm 0.26 \mathrm{~L}$ packed red cells, $3.8 \pm 0.143 \mathrm{~L}$ blood products (plasma, cryoprecipitate, platelets) and a mean of $7.8 \pm 6.3 \mathrm{~L}$ crystalloids of which $5.6 \pm 4.0 \mathrm{~L}$ were chloride-liberal and $2.4 \pm 1.4 \mathrm{~L}$ were chloride-restrictive fluids. Mean APACHE II score was 15.9 \pm 5.4 (range 4, 48), serum procalcitonin level $2.4 \mathrm{ngm} / \mathrm{ml}$ (IQR 3.1), proBNP $476 \mathrm{pg} / \mathrm{mL}$ (IQR 2,510) and 120 (76\%) patients were on a norepinephrine infusion. Seventy-eight (49.4\%) had pleural effusions; pleural drainage by pigtail catheters was carried out in 23 out of 78 patients (29.4\%). In the first 72 hours of ICU stay, transplant recipients were in a cumulative positive fluid balance of $12.7 \pm 7.8 \mathrm{~L}$ with $9 \pm 6 \mathrm{~L}$ crystalloids, $6.4 \pm 3.5 \mathrm{~L}$ colloids $(5 \%, 20 \%$ albumin) and $25 \pm 11.9 \mathrm{~L}$ chloride-liberal ( $0.9 \%$ saline, $5 \%$ albumin, $20 \%$ albumin) received. Blood products transfused were $4 \mathrm{~L}$ (IQR 4.8). There was no significant difference between the mean serum chloride levels in the chloride-liberal group compared to the chloride-restrictive group, $114 \pm 5.8$ versus $113 \pm 5.9, P>0.05$. No significant correlation was found between the mean serum chloride concentrations and the cumulative volumes of chloride-liberal fluids given, $P>0.05$ (see Table 1 and Figure 1).
Median ICU length of stay was five days (IQR 6), mean $8.4 \pm 12.5$ days. Patients were ventilated for a median of two days (IQR 2) with nine (5.7\%) patients subsequently undergoing tracheostomy. ICU mortality was $8.2 \%$ (13 patients); 28-day survival was 140 (88.6\%). Eight (5\%) recipients were readmitted to the ICU for the following: respiratory failure two, sepsis three, bleeding three. Mean time to readmission was $3.5 \pm 1.1$ days $(2,5)$.

\section{Outcomes}

AKI developed in 58 (36.4\%) patients; classified as risk in $30(52 \%)$, injury in $12(21 \%)$ and failure in $16(27 \%)$ patients. Ninety percent (53 patients) developed AKI within the first two postoperative days. All liver transplant patients, both the group that developed AKI and those that did not were on the calcineurin inhibitor, tacrolimus. Drug levels were routinely monitored and dosing adjusted accordingly. Thirty-nine (68.4\%) patients recovered fully, 13 (22.8\%) developed chronic renal failure and 10 (17.5\%) required long-term hemodialysis. AKI was significantly associated with ICU mortality, $P=0.001$ and 28 -day mortality, $P<0.001$. Mean serum chloride levels on the second postoperative day were significantly greater in patients who developed AKI compared to those who did not; $114 \pm 7.2$ versus $112 \pm 4.4$, $P=0.01$. The mean chloride levels on days one and three were not significantly different. There were no significant associations between mean serum chloride levels and the severity of renal failure (see Table 2).

\section{Univariate outcome data}

On univariate regression analysis, AKI was significantly associated with greater than $3,200 \mathrm{ml}$ of chloride-liberal fluids infused within the first postoperative day (HR 5.9, 95\% CI 2.64, 13.2, $P<0.001$ ), greater than $1,500 \mathrm{ml}$ colloids received in the OR (HR 1.97, 95\% CI 1.01, $3.8, P=0.046)$, vasopressor requirement for 48 hours posttransplant (HR 3.34, 95\% CI 1.55, 7.21, $P=0.002$ ), hyperchloremia at day 2 (HR 1.09, 95\% CI 1.01, 1.18, $P=0.015$ ) and preoperative MELD score (HR 1.08, 95\% CI 1.03, 1.13, $P=0.001$ ).

Delayed weaning from mechanical ventilation was associated with higher volumes of chloride-liberal fluids, $P=0.02$, higher colloid volumes, $P=0.015$, blood products transfused, $P=0.017$ and a cumulative positive fluid balance, $P=0.026$. Higher pretransplant MELD scores, $P=0.001$, male gender, $P=0.015$, transplant for hepatocellular carcinoma, $P=0.014$, crystalloid volume received in the first 72 hours, $P=0.034$, need for vasopressors at 48 hours, $P<0.001$ and 72 hours, $P=0.031$, AKI, $P<0.001$ and pleural effusion, $P=0.001$ were significantly associated with a prolonged ICU admission. Drainage of effusion was significantly associated with a reduced ICU stay, $P=0.007$ (see Tables 3 and 4). 
Table 1 Chemical compositions of fluids used in liver transplant recipients

\begin{tabular}{|c|c|c|}
\hline Fluid-type & Composition per 1 liter & Manufacturer \\
\hline \multicolumn{3}{|l|}{ crystalloids } \\
\hline \multirow[t]{2}{*}{ 0.9\% Sodium chloride, USP } & 154 mEq Sodium & \multirow[t]{2}{*}{ Baxter Healthcare Corp, Deerfield, IL, USA } \\
\hline & 154 mEq Chloride & \\
\hline \multirow[t]{2}{*}{ 0.45\% Sodium chloride, USP } & 77 mEq Sodium & \multirow[t]{2}{*}{ Baxter Healthcare Corp, Deerfield, IL, USA } \\
\hline & 77 mEq Chloride & \\
\hline \multirow[t]{5}{*}{ Lactated Ringer's injection, USP } & 130 mEq Sodium & \multirow[t]{5}{*}{ Baxter Healthcare Corp, Deerfield, IL, USA } \\
\hline & 4 mEq Potassium & \\
\hline & 3 mEq Calcium & \\
\hline & 109 mEq Chloride & \\
\hline & 28 mEq Sodium lactate & \\
\hline \multicolumn{3}{|l|}{ Colloids } \\
\hline \multirow[t]{2}{*}{ Human albumin $5 \%$ biotest } & \multirow{2}{*}{$\begin{array}{l}\text { Plasma protein 50gm ( } 96 \% \text { albumin), caprylate }(4 \mathrm{mmol} / \mathrm{l}) \text {, } \\
\mathrm{N} \text {-acetyl-DL-tryptophanate }(4 \mathrm{mmol} / \mathrm{l}) \text {, sodium ions }(145 \mathrm{mmol} / \mathrm{l}) \text {, } \\
\text { water for injections ad } 1,000 \mathrm{ml}\end{array}$} & Biotest Pharma GmbH \\
\hline & & Dreieich, Germany \\
\hline \multirow{2}{*}{$\begin{array}{l}\text { Human albumin } 20 \% \text { biotest } \\
\text { (given diluted in } 0.9 \% \text { normal saline) }\end{array}$} & \multirow{2}{*}{$200 \mathrm{~g} / \mathrm{l}$ (at least 95\% is human albumin) } & Biotest Pharma GmbH \\
\hline & & Dreieich, Germany \\
\hline
\end{tabular}

\section{Multivariate analysis}

After adjusting for covariates, infusion of greater than $3,200 \mathrm{ml}$ of chloride-liberal fluids (HR 6.25, 95\% CI 2.69, 14.5, $P<0.001$ ) and preoperative MELD score (HR 1.08, $95 \%$ CI 1.02, 1.15, $P=0.004$ ) remained significant predictors for AKI. Prolonged ICU stay was predicted by male gender, $P=0.014$, vasopressors $=0.003$ and the development of AKI, $P=0.013$ (see Table 5).

\section{Discussion}

In this observational study, we found that liver transplant recipients were more likely to develop AKI if they received larger volumes of chloride-liberal (hyperchloremic) fluids. This association was significant, after adjusting for baseline variables, for both $5 \%$ albumin in $0.9 \%$ saline and only $0.9 \%$ saline infusions. Patients who developed AKI had significantly higher serum chloride

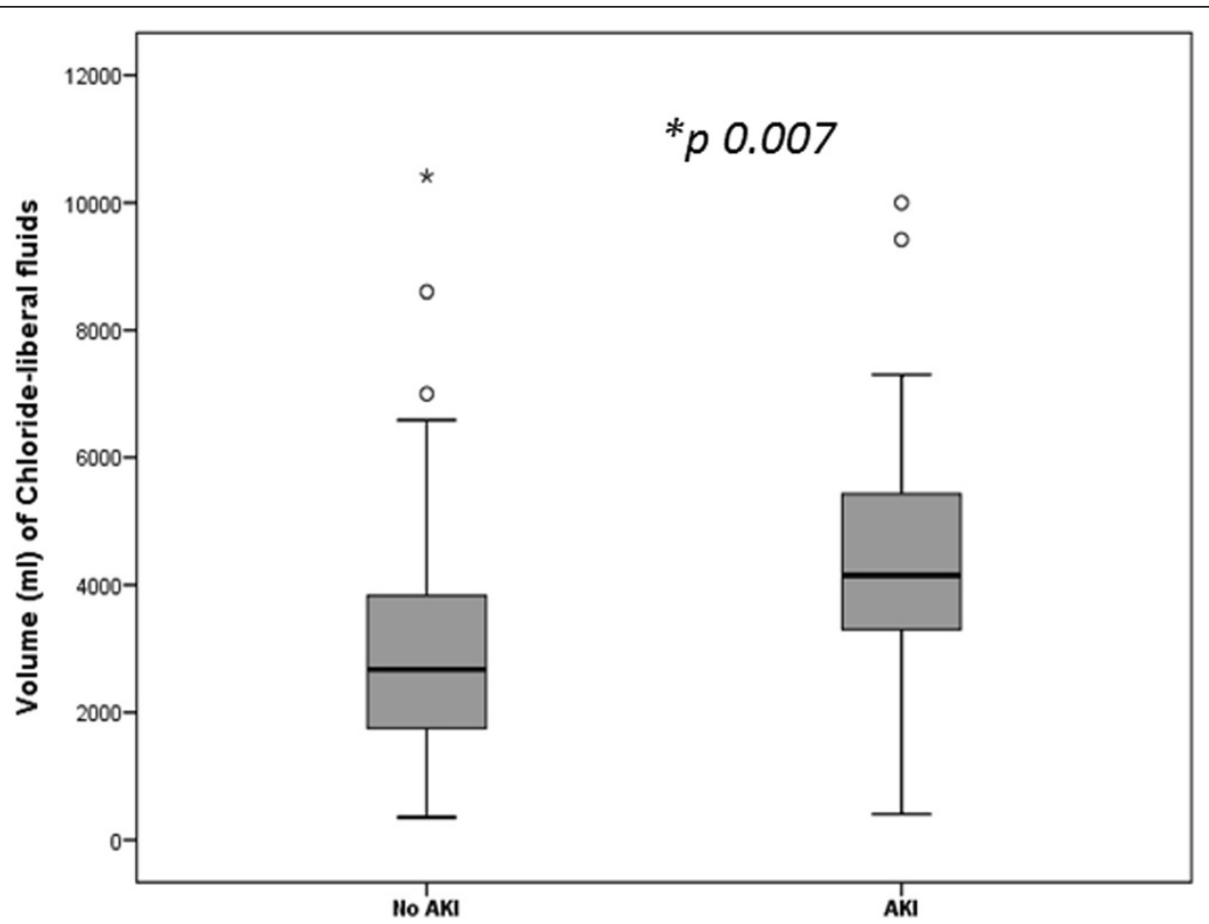

Figure 1 Relative volumes of chloride-liberal fluids received by liver transplant recipients with and without acute kidney injury (AKI). 
Table 2 Characteristics of liver transplant patients grouped by acute kidney injury according to the RIFLE classification

\begin{tabular}{l}
\hline Age, years \\
BMI \\
Pretransplant creatinine, \\
micromol/L \\
Pretransplant MELD score \\
Volume of chloride-liberal \\
liters (IQR) \\
Operating room \\
24 hours \\
48 hours \\
72 hours \\
Volume of chloride-restrictive \\
fluids, liters (IQR) \\
Operating room \\
24 hours \\
48 hours \\
72 hours \\
Volume of colloids, liters (IOR) \\
Operating room \\
24 hours posttransplant \\
48 hours posttransplant \\
72 hours posttransplant \\
Volume of packed $R B C$ \\
transfusions, liters (IQR) \\
Operating room \\
24 hours \\
48 hours \\
72 hours \\
Vlume of bood produCts
\end{tabular}

Volume of blood products transfused, liters (IQR)

Operating room
24 hours
48 hours posttransplant
72 hours posttransplant

Volume of crystalloids infused, liters (IQR)

Operating room
24 hours
48 hours
72 hours

Fluid balance, liters (IQR)

Operating room

24 hours

\begin{tabular}{lll}
$\begin{array}{l}\text { No AKI } \\
(\mathbf{n}=101)\end{array}$ & $\begin{array}{l}\text { AKI } \\
(\mathbf{n}=\mathbf{5 7})\end{array}$ & $\boldsymbol{P}$ value \\
\hline $51 \pm 14.2$ & $54 \pm 11.3$ & 0.13 \\
$26.4 \pm 6$ & $27.7 \pm 6.6$ & 0.19 \\
$76.2 \pm 40.2$ & $110.8 \pm 72.6$ & 0.001 \\
& & \\
$19.2 \pm 5.4$ & $21.8 \pm 9.1$ & 0.001
\end{tabular}

$\begin{array}{lll}4.7(5.7) & 6(6.8) & 0.23 \\ 2.1(1.2) & 3.8(2.7) & <0.001 \\ 0.64(1.06) & 1.7(1.5) & 0.007 \\ 0.35(0.65) & 1.07(0.87) & 0.55\end{array}$

$1.9(1.28) \quad 1.8(1.4) \quad 0.32$

$2.0(0.76) \quad 1.9(1.6) \quad 0.86$

$1.3(1.0) \quad 1.6(1.1) \quad 0.67$

$1.5(1) \quad 2.1(2.5) \quad 0.013$

$1.2(1.03) \quad 1.9(1.4) \quad 0.001$

$0.45(0.85) \quad 0.95(0.71) \quad 0.016$

$0.35(0.65) \quad 1.0(0.87) \quad 0.05$

$\begin{array}{lll}1.5(1.2) & 2.2(1.9) & 0.022 \\ 0.76(0.44) & 1.14(5.8) & 0.19 \\ 0.53(0.38) & 0.72(0.53) & 0.08 \\ 0.38(0.71) & 0.38(0.06) & 0.89\end{array}$

$\begin{array}{lll}3.2(2.3) & 3.8(3.2) & 0.17 \\ 0.95(2.1) & 2.1(4.8) & 0.14 \\ 0.72(0.53) & 0.97(1.2) & 0.63 \\ 0.63(1.5) & 0.51(0.32) & 0.78\end{array}$

$6(5.6) \quad 6(6) \quad 0.8$

$2.5(1.3) \quad 3.1(1.9) \quad 0.15$

$2.1(0.72) \quad 2.4(1.4) \quad 0.22$

$6.4(4.7) \quad 6.7(5.4) \quad 0.76$

$2.9(2.6) \quad 3.7(4.8) \quad 0.09$
$2(2) \quad 2(1.2) \quad 0.46$

$1.6(0.96) \quad 1.7(1.1) \quad 0.30$
Table 2 Characteristics of liver transplant patients grouped by acute kidney injury according to the RIFLE classification (Continued)

\begin{tabular}{|c|c|c|c|}
\hline 48 hours & $1.6(1.5)$ & $1.7(2.4)$ & 0.06 \\
\hline 72 hours & $0.947(2.07)$ & $0.623(1.54)$ & 0.93 \\
\hline \multicolumn{4}{|l|}{ Serum lactate, $\mathrm{mmol} / \mathrm{L}$} \\
\hline Day 1 & $4.2 \pm 2.9$ & $4.8 \pm 3.9$ & 0.26 \\
\hline Day 2 & $1.8 \pm 1.1$ & $2.1 \pm 1.6$ & 0.09 \\
\hline Day 3 & $1.4 \pm 0.5$ & $1.9 \pm 0.3$ & 0.046 \\
\hline \multicolumn{4}{|l|}{ Serum sodium, $\mathrm{mmol} / \mathrm{L}$} \\
\hline Day 1 & $146 \pm 5.2$ & $146.5 \pm 5.0$ & 0.57 \\
\hline Day 2 & $143 \pm 5.7$ & $145 \pm 3$ & 0.016 \\
\hline Day 3 & $144 \pm 2.3$ & $146 \pm 2.6$ & 0.002 \\
\hline \multicolumn{4}{|l|}{ Serum chloride, $\mathrm{mmol} / \mathrm{L}$} \\
\hline Day 1 & $114 \pm 5.7$ & $113 \pm 5.9$ & 0.76 \\
\hline Day 2 & $112 \pm 4.4$ & $114 \pm 7.2$ & 0.01 \\
\hline Day 3 & $110 \pm 4.6$ & $111 \pm 4.8$ & 0.18 \\
\hline \multicolumn{4}{|l|}{ Vasopressor requirement } \\
\hline At admission & $73(72 \%)$ & $47(82.5 \%)$ & 0.25 \\
\hline Day 1 & $3(3 \%)$ & $1(1.8 \%)$ & 0.64 \\
\hline Day 2 & $15(14.8 \%)$ & $21(36.8 \%)$ & 0.002 \\
\hline Day 3 & $4(4 \%)$ & $8(14 \%)$ & 0.056 \\
\hline Days on mechanical ventilation & $2.3 \pm 3.6$ & $6 \pm 7.1$ & 0.001 \\
\hline Length of ICU stay after transplant & $5.5 \pm 4.7$ & $13.4 \pm 19$ & 0.003 \\
\hline
\end{tabular}

levels compared to transplant recipients that did not develop AKI.

'Normal' saline or $0.9 \%$ saline contains supraphysiological levels of chloride ( $154 \mathrm{mmol} / \mathrm{L}$ as compared to Hartmann's solution, Ringer's lactate or Plasma-Lyte 148, all of which contain chloride concentrations that are lower (94 to $111 \mathrm{mmol} / \mathrm{L}$ ). Five percent albumin is available either as salt-poor or in sodium chloride (chloride concentration $128 \mathrm{mmol} / \mathrm{L}$ ). Intravenous infusions of chloride-liberal fluids have been associated with hyperchloremia and metabolic acidosis when administered in large volumes [26].

Our results show a detrimental effect on renal function with use of chloride-liberal fluids in the immediate postoperative period (up to 48 hours). Support for our findings comes from animal studies that have demonstrated reductions in GFRs, renal arteriolar vasoconstriction [27], and human volunteer studies that have shown reduced renal cortical tissue perfusion, renal blood flow velocity after infusions of hyperchloremic solutions. [28]. In controlled trials, chloride-liberal fluids compared to chloride-poor fluids have been linked to longer time to micturition [21], lower urine output [29] and in a recent 
Table 3 Demographic, fluids and outcome variables in liver transplant patients grouped by ICU length of stay

\begin{tabular}{|c|c|c|c|}
\hline & $\begin{array}{l}<5 \text { days ICU } \\
\text { stay }(n=78)\end{array}$ & $\begin{array}{l}\geq 5 \text { days ICU } \\
\text { stay }(n=80)\end{array}$ & $P$ value \\
\hline Male gender & $25(32 \%)$ & $41(51.2 \%)$ & 0.015 \\
\hline $\mathrm{HCC}$ & $33(42.3 \%)$ & $19(23.1 .7 \%)$ & 0.014 \\
\hline Pretransplant MELD score & $17 \pm 5.9$ & $21.3 \pm 8$ & 0.001 \\
\hline $\begin{array}{l}\text { Volume of crystalloids } \\
\text { received by } 72 \text { hours } m l(I Q R)\end{array}$ & $1,675(1,055)$ & $1,520(1,066)$ & 0.034 \\
\hline \multicolumn{4}{|l|}{$\begin{array}{l}\text { Volume of colloids received } \\
\text { by } \mathrm{ml}(\text { IQR) }\end{array}$} \\
\hline 24 hours posttransplant & $1,247(1,263)$ & $1,700(1,188)$ & 0.046 \\
\hline 48 hours posttransplant & $650(713)$ & $950(1095)$ & 0.015 \\
\hline $\begin{array}{l}\text { Undrained pleural effusion } \\
\text { posttransplant }\end{array}$ & $28(35.8 \%)$ & $50(62.5 \%)$ & 0.001 \\
\hline \multicolumn{4}{|l|}{ Vasopressors requirement } \\
\hline 48 hours posttransplant & $8(10.3 \%)$ & $28(35 \%)$ & 0.001 \\
\hline 72 hours posttransplant & $2(2.6 \%)$ & $10(12.5 \%)$ & 0.031 \\
\hline$A K I$ & $17(22 \%)$ & $40(50 \%)$ & $<0.001$ \\
\hline Early complications & $43(55.1 \%)$ & $50(62.5 \%)$ & 0.035 \\
\hline
\end{tabular}

AKI, acute kidney injury; HCC, hepatocellular carcinoma; ICU, intensive care unit; IQR, interquartile range; MELD, model for end-stage liver disease.

observational study of over 31,000 postoperative patients, $0.9 \%$ saline compared to 'balanced' crystalloids increased the risk of acute renal failure requiring dialysis [30]. Yunos et al., in a pre- and postintervention study on 1,530 critically ill patients found that a chloride-restrictive fluid

Table 4 Perioperative fluids in patients after liver transplant grouped by delayed weaning from mechanical ventilation

$\begin{array}{ll}<3 \text { days } & \geq 3 \text { days } \quad P \text { value } \\ \text { mechanical } & \text { mechanical } \\ \text { ventilation } & \text { ventilation } \\ (n=104) & (n=54)\end{array}$

Volume of blood products, ${ }^{*} \mathrm{ml}(\mathrm{QQR})$

\begin{tabular}{|c|c|c|c|}
\hline Operating room & $4,030(2391)$ & $5,321(4607)$ & 0.015 \\
\hline 24 hours posttransplant & $920(1551)$ & $3,028(3893)$ & 0.017 \\
\hline 48 hours posttransplant & $415(470)$ & 827 (1194) & 0.048 \\
\hline \multicolumn{4}{|l|}{ Volume of colloids, $\mathrm{ml}(I Q R)$} \\
\hline Operating room & $1,500(1875)$ & $2,421(850)$ & 0.032 \\
\hline 24 hours posttransplant & $1,842(1019)$ & $2,315(1205)$ & $<0.001$ \\
\hline 48 hours posttransplant & $625(669)$ & $1,193(933)$ & $<0.001$ \\
\hline 72 hours posttransplant & $675(881)$ & $700(883)$ & 0.015 \\
\hline \multicolumn{4}{|l|}{$\begin{array}{l}\text { Volume of chloride-liberal } \\
\text { fluids, } m /(I Q R)\end{array}$} \\
\hline Operating room & $5,000(7813)$ & $7,000(8434)$ & 0.027 \\
\hline 24 hours posttransplant & 3,397 (2868) & $3,725(2473)$ & 0.020 \\
\hline $\begin{array}{l}\text { Fluid balance at } 48 \text { hours } \\
\text { posttransplant, } \mathrm{ml}\end{array}$ & $1,725(1186)$ & $2,257(2102)$ & 26 \\
\hline
\end{tabular}

Includes packed cells, fresh frozen plasma, platelets, cryoprecipitate. IQR, interquartile range.
Table 5 Regression analysis for variables associated with acute kidney injury post-liver transplantation

\begin{tabular}{|c|c|c|c|}
\hline & $\begin{array}{l}\text { Hazard } \\
\text { ratio }\end{array}$ & $95 \% \mathrm{Cl}$ & $P$ value \\
\hline \multicolumn{4}{|l|}{ Univariate analysis } \\
\hline MELD score & 1.08 & $1.03,1013$ & 0.001 \\
\hline APACHE II score at admission to ICU & 1.08 & $1.03,1.15$ & 0.018 \\
\hline Colloids $\geq 1,500 \mathrm{ml}$ received in OR & 1.97 & $1.01,3.8$ & 0.046 \\
\hline $\begin{array}{l}\text { Chloride-liberal fluids } \geq 3,200 \mathrm{ml} \text { received } \\
\text { within the first } 24 \text { hours posttransplant }\end{array}$ & 5.9 & $2.64,13.2$ & 0.000 \\
\hline $\begin{array}{l}\text { Vasopressors requirement at } 2 \text { days } \\
\text { posttransplant }\end{array}$ & 3.34 & $1.55,7.21$ & 0.002 \\
\hline Serum chloride level at day 2 & 1.09 & $1.01,1.18$ & 0.015 \\
\hline \multicolumn{4}{|l|}{ Multivariate analysis } \\
\hline $\begin{array}{l}\text { Chloride-liberal fluids } \geq 3,200 \mathrm{ml} \text { received } \\
\text { within the first } 24 \text { hours posttransplant }\end{array}$ & 6.25 & $2.69,14.5$ & $<0.001$ \\
\hline Preoperative MELD score & 1.08 & $1.02,1.15$ & 0.004 \\
\hline
\end{tabular}

APACHE II, acute physiology and chronic health evaluation II; $\mathrm{Cl}$, confidence interval; ICU, intensive care unit; MELD, model for end-stage liver disease; OR, operating room.

strategy resulted in a significant reduction in AKI, need for RRT and increase in creatinine as compared to a control group given chloride-liberal fluids [23].

Possible explanations for this renal 'toxicity' of chlorideliberal fluids come from animal studies that have demonstrated renal vasoconstriction [22] and thromboxane release after chloride infusions [20]. Chloride infusions increase delivery to the macula densa that stimulates glomerulotubular feedback leading to afferent arteriole constriction, mesangial contraction and resultant decrease in GFR [31].

Patients in our study received both $5 \%$ albumin in saline and $20 \%$ albumin in saline. Though it is possible that the observed renal dysfunction resulted from hyperoncotic albumin, the data on $20 \%$ albumin is so far inconclusive. A recent cohort study on 1,000 patients found a higher risk of renal injury and failure with the use of hyperoncotic albumin (OR 5.99) [32], however, a contradictory result was reported from two meta-analyses that concluded no harmful effects of hyperoncotic resuscitation [33,34]. The SAFE study that compared albumin and saline found no difference in adverse outcomes [35].

Fluid overload leads to organ dysfunction due to interstitial edema and visceromegaly. The limited accommodative capacity of the encapsulated kidney causes increased interstitial hydrostatic pressures with reduced renal perfusion and filtration [36]. Additionally, a fluid overload state contributes to third spacing, ascitic fluid accumulation and abdominal compartment syndrome [37]. Cumulative fluid overload has been linked to poor outcomes in all groups (pediatric, septic, postoperative) of critically ill patients with prolonged days on mechanical ventilation, ICU stay and mortality $[16,17,38-43]$. Recovery of renal 
function in patients on RRT is also determined by overall fluid balance $[17,38,42]$. In our study, a cumulative positive fluid balance increased the duration of stay in ICU.

A limitation of our study is that the observational design does not establish a causal relationship of hyperchloremic fluid excess with the development of AKI in liver transplant recipients. These associations may be subject to bias from selection, confounding or random error. We attempted to control for confounders by using regression analysis. Another limitation is the external validity or generalizability of our results to other liver transplant recipients since we collected data only from a single institution.

\section{Conclusions}

In summary, large infusions of chloride-liberal fluids may predict a higher risk of AKI in liver transplant recipients. Our findings support the hypothesis that 'routine' intravenous fluids may not be routine and in themselves be associated with organ dysfunction. Our results can be used to build hypotheses for further controlled trials.

\section{Key messages}

- Chloride-liberal fluids may cause renal dysfunction

- Large volumes $(>3,200 \mathrm{ml})$ of chloride-liberal fluids infused in the first 24 hours after liver transplantation were associated with a higher risk of AKI.

\begin{abstract}
Abbreviations
AKI: acute kidney injury; APACHE II: acute physiologic and chronic health evaluation II; BMI: body mass index; Cl: confidence interval; GFR: glomerular filtration rate; HR: hazard ratio; ICU: intensive care unit; IQR: interquartile range; MELD: model for end-stage liver disease; OR: odds ratio; RIFLE: risk, injury, failure, loss, end-stage renal failure; RRT: renal replacement therapy; SD: standard deviation.
\end{abstract}

\section{Competing interests}

The authors declare that they have no competing interests.

\section{Authors' contributions}

AN participated in the design of the study, collected the data, analyzed and interpreted the data, drafted the manuscript, and revised the manuscript critically for important intellectual content. NS conceived the study, participated in the design of the study, made the figures and table, analyzed and interpreted the data, drafted the manuscript, and revised the manuscript critically for important intellectual content. AH, MJ, HAS and BB participated in the design of the study, collected the data, and participated in the coordination of the study. YS and DB participated in the design and coordination of the study and participated in the critical review of the final manuscript. All authors have given final approval of the version to be published.

\section{Acknowledgements}

There was no special funding for the study. The design, collection, analysis and interpretation of data, plus writing and publication of the manuscript were done by the authors without participation or influence from any of the funding sources.

\section{Author details}

Department of Adult Critical Care Medicine, King Faisal Specialist Hospital and Research Centre, At Takhassusi, Al Madhar Ash Shamali, Riyadh 12713, Saudi Arabia. ${ }^{2}$ Department of Nursing Services, King Faisal Specialist Hospital and Research Centre, At Takhassusi, Al Madhar Ash Shamali, Riyadh 12713, Saudi Arabia. ${ }^{3}$ Organ transplant Centre, King Faisal Specialist Hospital and Research Centre, At Takhassusi, Al Madhar Ash Shamali, Riyadh 12713, Saudi Arabia.

Received: 10 June 2014 Accepted: 28 October 2014

Published online: 19 November 2014

\section{References}

1. Zhu M, Li Y, Xia Q, Wang S, Qiu Y, Che M, Dai H, Qian J, Ni Z, Axelsson J, Yan Y: Strong impact of acute kidney injury on survival after liver transplantation. Transplant Proc 2010, 42:3634-3638.

2. Karapanagiotou A, Kydona C, Dimitriadis C, Sgourou K, Giasnetsova T, Fouzas I, Imvrios G, Gritsi-Gerogianni N: Acute kidney injury after orthotopic liver transplantation. Transplant Proc 2012, 44:2727-2729.

3. O'Riordan A, Wong V, McQuillan R, McCormick PA, Hegarty JE, Watson AJ: Acute renal disease, as defined by the RIFLE criteria, post-liver transplantation. Am J Transplant 2007, 7:168-176.

4. Barri YM, Sanchez EQ, Jennings LW, Melton LB, Hays S, Levy MF, Klintmalm GB: Acute kidney injury following liver transplantation: definition and outcome. Liver Transpl 2009, 15:475-483.

5. Watt KD, Pedersen RA, Kremers WK, Heimbach JK, Charlton MR: Evolution of causes and risk factors for mortality post-liver transplant: results of the NIDDK long-term follow-up study. Am J Transplant 2010, 10:1420-1427.

6. Wei Y, Zhang L, Lin H, Li J, Li B, Yan L, Wen T, Zeng Y, Lu S: Factors related to post-liver transplantation acute renal failure. Transplant Proc 2006, 38:2982-2984

7. Pawarode A, Fine DM, Thuluvath PJ: Independent risk factors and natural history of renal dysfunction in liver transplant recipients. Liver Transp/ 2003, 9:741-747.

8. Chen J, Singhapricha T, Hu KQ, Hong JC, Steadman RH, Busuttil RW, Xia WW: Postliver transplant acute renal injury and failure by the RIFLE criteria in patients with normal pretransplant serum creatinine concentrations: a matched study. Transplantation 2011, 91:348-353.

9. Sanchez EQ, Gonwa TA, Levy MF, Goldstein RM, Mai ML, Hays SR, Melton LB, Saracino G, Klintmalm GB: Preoperative and perioperative predictors of the need for renal replacement therapy after orthotopic liver transplantation. Transplantation 2004, 78:1048-1054.

10. Bilbao I, Charco R, Balsells J, Lazaro JL, Hidalgo E, Llopart L, Murio E, Margarit C: Risk factors for acute renal failure requiring dialysis after liver transplantation. Clin Transpl 1998, 12:123-129.

11. Lima EQ, Zanetta DM, Castro I, Massarollo PC, Mies S, Machado MM, Yu L: Risk factors for development of acute renal failure after liver transplantation. Ren Fail 2003, 25:553-560.

12. Lebron Gallardo M, Herrera Gutierrez ME, Seller Perez G, Curiel Balsera E, Fernandez Ortega JF, Quesada Garcia G: Risk factors for renal dysfunction in the postoperative course of liver transplant. Liver Transp/ 2004. 10:1379-1385.

13. Cabezuelo JB, Ramirez P, Rios A, Acosta F, Torres D, Sansano T, Pons JA, Bru M, Montoya M, Bueno FS, Robles R, Parrilla P: Risk factors of acute renal failure after liver transplantation. Kidney Int 2006, 69:1073-1080

14. Herrler T, Tischer A, Meyer A, Feiler S, Guba M, Nowak S, Rentsch M, Bartenstein P, Hacker M, Jauch KW: The intrinsic renal compartment syndrome: new perspectives in kidney transplantation. Transplantation 2010, 89:40-46.

15. Alsous F, Khamiees M, DeGirolamo A, Amoateng-Adjepong Y, Manthous CA: Negative fluid balance predicts survival in patients with septic shock: a retrospective pilot study. Chest 2000, 117:1749-1754.

16. Payen D, de Pont AC, Sakr Y, Spies C, Reinhart K, Vincent JL: A positive fluid balance is associated with a worse outcome in patients with acute renal failure. Crit Care 2008, 12:R74

17. Bouchard J, Soroko SB, Chertow GM, Himmelfarb J, Ikizler TA, Paganini EP, Mehta RL: Fluid accumulation, survival and recovery of kidney function in critically ill patients with acute kidney injury. Kidney Int 2009, 76:422-427. 
18. Bagshaw SM, Brophy PD, Cruz D, Ronco C: Fluid balance as a biomarker: impact of fluid overload on outcome in critically ill patients with acute kidney injury. Crit Care 2008, 12:169.

19. Reydellet L, Blasco V, Mercier MF, Antonini F, Nafati C, Harti-Souab K, Leone M, Albanese $\mathrm{J}$ : Impact of a goal-directed therapy protocol on postoperative fluid balance in patients undergoing liver transplantation: A retrospective study. Ann Fr Anesth Reanim 2014, 33:e47-e54.

20. Bullivant EM, Wilcox CS, Welch WJ: Intrarenal vasoconstriction during hyperchloremia: role of thromboxane. Am J Physiol 1989, 256:F152-F157.

21. Williams EL, Hildebrand KL, McCormick SA, Bedel MJ: The effect of intravenous lactated Ringer's solution versus $0.9 \%$ sodium chloride solution on serum osmolality in human volunteers. Anesth Analg 1999, 88:999-1003.

22. Wilcox CS: Regulation of renal blood flow by plasma chloride. J Clin Invest 1983, 71:726-735.

23. Yunos NM, Bellomo R, Hegarty C, Story D, Ho L, Bailey M: Association between a chloride-liberal vs chloride-restrictive intravenous fluid administration strategy and kidney injury in critically ill adults. JAMA 2012, 308:1566-1572.

24. von Elm E, Altman DG, Egger M, Pocock SJ, Gotzsche PC, Vandenbroucke JP: Strengthening the Reporting of Observational Studies in Epidemiology (STROBE) statement: guidelines for reporting observational studies. BMJ 2007, 335:806-808

25. Bellomo R, Ronco C, Kellum JA, Mehta RL, Palevsky P: Acute renal failure - definition, outcome measures, animal models, fluid therapy and information technology needs: the Second International Consensus Conference of the Acute Dialysis Quality Initiative (ADQI) Group. Crit Care 2004, 8:R204-R212.

26. Wakim KG: "Normal" 0.9 per cent salt solution is neither "normal" nor physiological. JAMA 1970, 214:1710.

27. Wan L, Bellomo R, May CN: Bolus hypertonic or normal saline resuscitation in gram-negative sepsis: systemic and regional haemodynamic effects in sheep. Crit Care Resusc 2011, 13:262-270.

28. Chowdhury AH, Cox EF, Francis ST, Lobo DN: A randomized, controlled, double-blind crossover study on the effects of $2-L$ infusions of $0.9 \%$ saline and plasma-lyte ${ }^{\oplus} 148$ on renal blood flow velocity and renal cortical tissue perfusion in healthy volunteers. Ann Surg 2012, 256:18-24.

29. Wilkes NJ, Woolf R, Mutch M, Mallett SV, Peachey T, Stephens R, Mythen MG: The effects of balanced versus saline-based hetastarch and crystalloid solutions on acid-base and electrolyte status and gastric mucosal perfusion in elderly surgical patients. Anesth Analg 2001, 93:811-816.

30. Shaw AD, Bagshaw SM, Goldstein SL, Scherer LA, Duan M, Schermer CR, Kellum JA: Major complications, mortality, and resource utilization after open abdominal surgery: $0.9 \%$ saline compared to Plasma-Lyte. Ann Surg 2012, 255:821-829.

31. Salomonsson M, Gonzalez E, Kornfeld M, Persson AE: The cytosolic chloride concentration in macula densa and cortical thick ascending limb cells. Acta Physiol Scand 1993, 147:305-313.

32. Schortgen F, Girou E, Deye N, Brochard L: The risk associated with hyperoncotic colloids in patients with shock. Intensive Care Med 2008, 34:2157-2168

33. Wiedermann CJ, Dunzendorfer S, Gaioni LU, Zaraca F, Joannidis M: Hyperoncotic colloids and acute kidney injury: a meta-analysis of randomized trials. Crit Care 2010, 14:R191.

34. Jacob M, Chappell D, Conzen P, Wilkes MM, Becker BF, Rehm M: Small-volume resuscitation with hyperoncotic albumin: a systematic review of randomized clinical trials. Crit Care 2008, 12:R34

35. Finfer S, Bellomo R, Boyce N, French J, Myburgh J, Norton R: A comparison of albumin and saline for fluid resuscitation in the intensive care unit. N Engl J Med 2004, 350:2247-2256.

36. Stone $\mathrm{HH}$, Fulenwider JT: Renal decapsulation in the prevention of post-ischemic oliguria. Ann Surg 1977, 186:343-355.

37. Vidal MG, Ruiz Weisser J, Gonzalez F, Toro MA, Loudet C, Balasini C, Canales $H$, Reina R, Estenssoro E: Incidence and clinical effects of intra-abdominal hypertension in critically ill patients. Crit Care Med 2008, 36:1823-1831.

38. Bellomo R, Cass A, Cole L, Finfer S, Gallagher M, Lee J, Lo S, McArthur C, McGuiness S, Norton R, Myburgh J, Scheinkestel C, Su S: An observational study fluid balance and patient outcomes in the Randomized Evaluation of Normal vs Augmented Level of Replacement Therapy trial. Crit Care Med 2012, 40:1753-1760
39. Boyd JH, Forbes J, Nakada TA, Walley KR, Russell JA: Fluid resuscitation in septic shock: a positive fluid balance and elevated central venous pressure are associated with increased mortality. Crit Care Med 2011, 39:259-265.

40. Brandstrup B, Tonnesen $H$, Beier-Holgersen $R$, Hjortso E, Ording H, Lindorff-Larsen K, Rasmussen MS, Lanng C, Wallin L, Iversen LH, Gramkow CS, Okholm M, Blemmer T, Svendsen PE, Rottensten $\mathrm{HH}$, Thage B, Riis J, Jeppesen IS, Teilum D, Christensen AM, Graungaard B, Pott F: Effects of intravenous fluid restriction on postoperative complications: comparison of two perioperative fluid regimens: a randomized assessor-blinded multicenter trial. Ann Surg 2003, 238:641-648.

41. Gillespie RS, Seidel K, Symons JM: Effect of fluid overload and dose of replacement fluid on survival in hemofiltration. Pediatr Nephrol 2004 19:1394-1399

42. Heung M, Wolfgram DF, Kommareddi M, Hu Y, Song PX, Ojo AO: Fluid overload at initiation of renal replacement therapy is associated with lack of renal recovery in patients with acute kidney injury. Nephrol Dial Transplant 2012, 27:956-961.

43. Wiedemann HP, Wheeler AP, Bernard GR, Thompson BT, Hayden D, deBoisblanc B, Connors AF Jr, Hite RD, Harabin AL: Comparison of two fluid-management strategies in acute lung injury. N Engl J Med 2006, 354:2564-2575.

doi:10.1186/s13054-014-0625-7

Cite this article as: Nadeem et al:: Chloride-liberal fluids are associated with acute kidney injury after liver transplantation. Critical Care 2014 18:625.

\section{Submit your next manuscript to BioMed Central and take full advantage of:}

- Convenient online submission

- Thorough peer review

- No space constraints or color figure charges

- Immediate publication on acceptance

- Inclusion in PubMed, CAS, Scopus and Google Scholar

- Research which is freely available for redistribution 